\title{
The Impact of Swain's Pushed Output Hypothesis on Enhancing Iranian EFL Learners' Reading Comprehension
}

\author{
Ehsan Namaziandost ${ }^{1 *}$, Mehdi Nasri ${ }^{1}$, Sheida Ahmadi ${ }^{2}$ \\ ${ }^{I}$ PhD Candidate in TEFL, Department of English, Faculty of Humanities, Shahrekord Branch, Islamic Azad \\ University, Shahrekord, Iran \\ ${ }^{2}$ State University of Malayer, Hamedan, Iran
}

*Corresponding Author: Ehsan Namaziandost, PhD Candidate in TEFL, Department of English, Faculty of Humanities, Shahrekord Branch, Islamic Azad University, Shahrekord, Iran

\begin{abstract}
This study aimed to investigate the impact of Swain's push out hypothesis (1985) on promoting Iranian EFL Learners' reading comprehension. To fulfill, 50 homogeneous male pre-intermediate students were chosen and randomly divided into two equal groups, namely an experimental group $(n=25)$ and a control group $(n=25)$. Then they were pretested through a researcher-made reading comprehension pre-test. Afterward that the experimental group received the treatment based on Swains' push out task, while the control group did not receive any treatment. At the end of the treatment, a posttest was run to check the effect of the treatment. After collecting the data, One-way ANCOVA was used to analyze the results. The results showed that experimental group significantly outperformed the control group on the post-test ( $p<.05)$.These results prove that teaching on the basis of the Swains' push out hypothesis was successful to enhance the students' reading comprehension as well as their performance.
\end{abstract}

Keywords: Push Output Hypothesis, Reading comprehension, Pre-intermediate students

\section{INTRODUCTION}

These days, English is viewed as a widespread language. It is the language all students attempt to learn and ace. Students who need to learn English must have the option to ace the four English aptitudes: Reading, speaking, reading and listening. The coordination of the four aptitudes is fundamental in the learning procedure. Learners should be powerful students through their support, collaboration and doing the push out assignments in the best possible manner. Reading aptitude, as one of the four English abilities, assumes a fundamental job in the obtaining of English as an unknown language. It is an essential ability for instructors and educators to guarantee that students procure sufficient vocabulary to have the option to peruse and appreciate any content great. Reading appreciation relies upon numerous segments, for example, vocabulary, language structure, attachment and lucidness of thoughts, articulation, spelling, and so forth. These parts are basic in language securing. In any case, there is a mind-boggling dynamic connection between readingcomprehension capacity and vocabulary size (Hu \& Nation, 2000; Nasri, Namaziandost, \& Akbari, 2019). "without vocabulary nothing can be passed on" Wilkins (1972) (pp. 111-112). Vocabulary is a key part to English language instructing in light of the fact that without those adequate vocabulary, our students can't express their very own thoughts and emotions. The deficiency in vocabulary for EL students will prompt an absence of correspondence among the speakers, which is a noteworthy issue in acing the language (Abedi, Keshmirshekan, \&Namaziandost, 2019).

Vocabulary acquisitionis a crucial segment in language-learning and language training that must be considered in improving reading and writing perception, even the information of English punctuation. Laufer and Sim (1985) asserted that so as to gain an unknown language, students need to have adequate vocabulary, and topic information, and syntactic structure. Nagy, Herman and Anderson (1985), and Nagy and Herman (1987) showed that vocabulary is the real facilitator of reading. It helps students in comprehension the content in a legitimate manner. Students, who have a decent capacity of vocabulary, are relied upon to accomplish better reviews in their considering. There is no uncertainty that reading perception related straight forwardly to the vocabulary information of 
student's language. Anderson and Freebody (1981) express that so as to evaluate how well that reader comprehends the content, it is imperative to know the general vocabulary information of the reader. Nagy and Herman (1987) express that instructors should show up the learners to broad reading, that lead to vocabulary development since vocabulary is viewed as an essential facilitator of reading execution (Nagy, Herman \& Anderson, 1985; Nagy \& Herman, 1987; Namaziandost, Nasri, \&Keshmirshekan, 2019). In his investigation, Laufer's (1992) finds that learners who have under 3000-word families couldn't peruse well paying little respect to their scholastic capacities, while learners with vocabulary sizes of beyond what 5000 could peruse well in their L2.

The National Reading Panel (2000) (NRP) portrayed reading perception as "a complex process procedure and it is a deliberate intuition during which significance is developed through communications among content and reader. The substance of importance is impacted by the content and by the reader's earlier information and experience that are applied as a powerful influence for it "(pp. 4-5).

NRP expressed that there are three central point influence reading appreciation. Initially, vocabulary guidance which has a significant job in reading perception as a subjective and intelligent procedure. Furthermore, dynamic intuitive vital procedures. The dynamic association that happens among students and their educators will prompt a superior learning and comprehension. Thirdly, the readiness of educators who are the principle facilitator in the intelligent vital procedures to build up the reading perception of their learners. It vital for all educators to set up their training subjects positively as it helps in encouraging the students' perception to the subjects they are learning. It is realized that great planning will prompt a superior support from all students (Namaziandost\&Nasri, 2019b). Reading comprehension techniques are of incredible worth and concern. Systems are imperative to defeat the comprehension issues and impediments, help readers grasp the content, connect with them seriously with the content, and afterward they become great readers and beneficiaries (Namaziandost\&Nasri, 2019a).

Swain (1985) states that: "To accomplish local speaker fitness, the significance of 'arranging signifying' should be stretched out past that standard feeling of just 'conveying the desired information'. Essentially communicating as the need should arise can and occurs with syntactically freak structures and sociolinguistically unseemly language" (p.248).

Many researchers (Gass, 1997; Mirshekaran, Namaziandost, \& Nazari, 2018; Namaziandost, Rahimi Esfahani, Nasri, \&Mirshekaran, 2018; Nasri, Biria, \& Karimi, 2018; Nasri\&Biria, 2017) have contended that subsequent language or unknown language students create linguistic exactness in their second language through 'exchange of signifying' in light of the fact that they keep up that fathomable info, which was created by Krashen 1980 (what Krashen calls "I + 1 information", isn't sufficient for L2 procurement and learning. In spite of there is a general comprehension among specialists that intelligible info is an imperative segment of source language obtaining (SLA), most have affirmed that fathomable contribution for L2 guidance is deficient. Long (1996) states that the most ideal approach to help L2 or remote students to be local speaker ability is to draw in them in exchange of importance. At the point when learners are occupied with the learning procedure, it is normal that it will encourage their learning (Namaziandost, Abedi, \&Nasri, 2019).

Swain utilizes numerous terms identified with the conceivable yield, as 'arranged yield', 'pushed yield' or simply 'yield' or yield speculation, to assist learners with comprehension language that contains sentence structure and vocabulary through the assistance of logical hints, and information of the significance of words. Swain firmly brought up the job of push out theory as an adequate factor for language securing Swain expresses that language procurement needs to join the idea of being 'pushed' close to the conveyance of a message that is passed on rationally, and suitably (Hashemifardnia, Namaziandost, \&Shafiee, 2018). This demonstration of "pushing solicits students to endeavor that powers them to process language all the more profoundly and effectively. Students are urged to recreate language from a book with many yield errands and exercises, for example, the dictogloss (Swain, 2000). As indicated by her, it is the most ideal approach to test the one's semantic learning by utilizing that information in some profitable ways; regardless of whether it is showing an idea to somebody or writing program. While on account of language picking up, utilizing the etymological information by getting a basic thought over, or altering a past expression. The analysts guarantee that 
when students are pushed to create language and to convey the message viably, they may see the phonetic structures in the info and therefore the fruitful learning may occur thus. Students need to accept that vocabulary is significant during the time spent appreciating writings. It is imperative to connect with learners in the yield exercises which are considered as a helpful facilitator to procure the language and to accomplish the language fitness (Namaziandost\&Shafiee, 2018). Along these lines, so as to grasp any content, students need to build their vocabulary development. Leeser, (2008) demonstrate that pushed yield can actuate the students to process input successfully.

The significance of Push Out Hypothesis which was proposed in 1985 has been inspected by numerous investigates. Kowal and Swain (1997), see that learners who chipping away at three distinct sorts of collaborative tasks (dictogloss, cloze, and editing) in a French submersion program. They see the hole between what learners needed to state and what they had the option to state. This happened essentially as learners were "pushed" to create the language. Learners ought to be urged to utilize and push out the language else; they won't have the option to ace it. In doing such a procedure it is relied upon to accomplish the normal learning results (Hashemifardnia, Namaziandost, \&Sepehri, 2018).

Shekary (2004) conducts an examination to look at the job of arrangement of significance and seeing in SLA advancement on the internet. The consequences of her investigation demonstrate that seeing turned out to be better when it occurred in online dealings. In addition, she sees that the events of seeing were superior to those in disconnected settings. Izumi and Bigelow (2000), and Izumi et al. (1999) research the impacts of yield on the students' ensuing seeing of just as concentrating on consequent info. They found that students accomplished evident advancement if the students are placed, all things considered, yield circumstances. Izumi (2002) proposes that when students are urged to deliver yield, they will have the option to improve brings about learning L2 than those students who are not allowed to create enough yield. The more they are urged to utilize the language, the more they will learn and ace it. Learners ought to be placed in genuine circumstances to urge them to utilize the yield in a viable and valuable manner.

Zhang (2009), and so as to build up the oral familiarity with the EFL setting, attempts to reveal the insight into the significance and the job of info, association and yield from both hypothetical and observational perspectives. To accomplish the motivation behind the examination, two instruments were utilized: trial of oral fluenc and eye to eye interviews. The discoveries of the examination uncover that it is feasible for non-local to build up their oral familiarity through productive and powerful information, communication and yield in EFL. Also, he poses the accompanying inquiry: "For what reason did the most Chinese English students neglect to communicate in English smoothly?" He finds that numerous reasons could remain against communicating in English fluidly, for example, the absence of viable info and yield, the absence of want to cooperate with others. Also, he finds that the Chinese learners didn't give a great deal of consideration for both language frames just as composed tests. The absence of certainty and want in utilizing and communicating in the language may influence adversely towards learning the language.

Abadikhah and Zarrabi (2011) lead an examination to investigate the incredible impact of push out undertaking on learning verbal morphemes by Iranian EFL students. To accomplish the reason for the examination, two gatherings of students from youthful grown-up classes. Every one of the members were male learners. Their age went from 13-15. Two gatherings were utilized in the examination. The push out gathering comprising of 20 students and a control gathering comprising of 18 students. The members in the two gatherings got pretest and posttest. The discoveries of the examination demonstrate that there was a noteworthy distinction among appreciation and creation of objective structures by the students. In addition, the outcomes uncovered that the push out gathering and in the wake of getting the treatment beat the control gathering, moreover, the examination demonstrate that members in the control gathering didn't; prevail with regards to demonstrating a reasonable improvement in their creation in spite of that they got a quantifiable gains in appreciating the objective etymological structure.

Rahimian (2013) examines the impacts of second language (L2) creation on L2 students' interlanguage (IL) adjustments. To accomplish the motivation behind the investigation, the specialists think about between English L2 students' yield creation and IL adjustment in performing two distinctive assignment types, single direction and two-way undertakings. The consequences of the 
investigation demonstrated that the L2 student members had the option to alter their yield during arrangement of significance in both single direction and two-way errands superior to anything what they had before doing the examination. To examine the job of push out assignments in building up an objective subsequent to getting an info, Basterrechea, Mayo, and Leeser (2014) direct an investigation to gauge that point. The example of the investigation comprised of sixteen immature students from a flawless Content and Language Integrated Learning (CLIL) study hall. They were approached to complete conveyed a multi-arrange dictogloss task in a shared and individual structure. The analysts pursue a specific model to accomplish the reason for the investigation. The members did various undertakings, for example, tune in and scribble down catchphrases, and content recreation. At that point the members were approached to tune in to the content indeed so as to contrast it and their generation. The consequences of the investigation uncovered that pushed errands allowed the students the chance to see formal parts of language positively.

Mahmoud Abadi, Soleimani, Jafarigohar, and Iravani (2015) lead an examination to look at the impact of push out in showing the vocabulary errands and its job in improving the information of vocabulary by EFL students. The example of the investigation comprised of 103 basic level. The majority of the members were female Iranian EFL students. The example of the investigation was haphazardly partitioned into three gatherings: input-just, input yield, and yield info gatherings. Every one of the members were approached to take an arrangement test just as a vocabulary pretest. To accomplish the reasons for the examination, the students in the info gathering got just information undertakings, while the members in the other two gatherings got both contributions just as yield assignments in various groupings. From that point onward, every one of the members in the three gatherings took a vocabulary posttest. The discoveries of this investigation uncovered that exhibiting the vocabulary errands in the succession of yield have an incredible constructive outcome for the members the two push out gatherings contrasted and the consequences of the members in the gathering that didn't get any treatment. The constructive outcome showed up in giving the members in the push out gatherings the capacity to see vocabulary learning hole and to build up their vocabulary information.

From the above hypothetical and observational contentions, we see that there are a few investigations that attempted to inspect the impact of push out undertakings in creating unknown language learning. They demonstrate that enlisting learners in the yield exercises is viewed as a helpful facilitator to obtain the language and to accomplish the native-speakers competence (Namaziandost, Sabzevari, and Hashemifardnia, 2018). It is normal that the outcomes just as the discoveries of this investigation can be useful and valuable to demonstrate that placing students in genuine push out undertakings will prompt improve and build up their reading execution(Namaziandost, Fatahi, \&Shafiee, 2019).

\subsection{Purpose, Question, and Null Hypothesis of the Study}

The main objective of this study was to check the impact of push output in language acquisition that is based on Swain's push output hypothesis (1985) on promoting Iranian language learners' reading skill. More specifically, the study tried to answer the following main question:

RQ 1. Is there any significant difference between Iranian EFL learners' reading comprehension when they are instructed in push output vocabulary instruction compared to the traditional instructions?

Based on the above-mentioned question, the following null hypothesis was formulated:

H0 1.There is not any significant difference between Iranian EFL learners' reading comprehension when they are instructed in push output vocabulary instruction compared to the traditional instructions

\subsection{Statement of the Problem}

Hosseini, Nasri, and Afghari (2017) affirms that the Iranian EFL college just as school learners experience a great deal of troubles when they are approached to peruse any content, he expresses that they can't recognize the primary thought in a reading content, and distinguish supporting data. They likewise can't relate what they read to their experience information, distinguish connections among thoughts, make determinations from the content, and clarify the writers' motivation for writing the content. Azadi, Biria, and Nasri (2018) clarify that building vocabulary through reading causes readers to speak with others. Numerous learners face a ton of challenges when they take part in reading exercises because of the absence of vocabulary that they have. This reality is a primary factor 
behind the absence of complete comprehension to the given writings. One may concur that this circumstance is a similar when discussing Iranian college learners (Namaziandost, Hashemifardnia, \&Shafiee, 2019).

Another issue is that learners just as instructors couldn't care less about the significance of vocabulary during the time spent appreciating writings as reading is an essential expertise in the procurement of unknown language learning. The measure of perception to the content depends predominantly on the measure of vocabulary that learners know. Also, an extraordinary issue emerges when educators and learners don't give a ton of consideration regarding the thought which recommends that presenting learners to concentrated reading is extremely a valuable and significant system to build the vocabulary development among them as it is considered, incredible facilitator towards a decent reading exhibition (Namaziandost, Ahmadi, \&Keshmirshekan, 2019).

Additionally, it is accepted that not many educators take a gander at the push out theory as an extraordinary facilitator to upgrade reading perception, which likewise prompts improve the learning of English syntax. Moreover, the analysts have noticed that the capacity of English language educators at Iranian colleges is still beneath the base ability of showing reading enough the same number of them are as yet utilizing the conventional old procedures in showing reading exercises (Namaziandost, Rahimi Esfahani, \& Ahmadi, 2019). Accordingly, the absence of vocabulary is noted among most of learners at Jordanians optional and college learners. This reality can be seen from the learners' outcomes in the reading tests whether on the national or worldwide level. Swain (1985) states that when students produce second language, particularly when they experience trouble in conveying their significance in the L2, they are pushed to alter their yield, and accordingly the yield may expand their perception capacity.

\subsection{Significance of the Study}

Since there is an extraordinary need to investigate the significance of vocabulary information in learning English as an unknown language, it is normal that the discoveries and the consequences of this examination may furnish the college educators with the vital experiences and suggestions that help in expanding their learners' vocabulary learning, which prompts improve their reading execution. What's more, it might likewise reveal the insight into the significance of push out speculation on creating Jordanian college learners' reading execution (Namaziandost, Nasri, Rahimi Esfahani, and Keshmirshekan 2019). Besides, the specialists feel that the discoveries of the present investigation could be useful to the instructors through furnishing them with the significance of applying some of reading cognizance and evaluation methodologies and the need to transform them to suit the reason for the reading task. Besides, this investigation is a decent chance to urge different specialists to do further examinations for other instructive levels and on other language aptitudes, for example, listening, speaking or writing so as to impart the outcomes and experience to different educators. In this manner, the discoveries of the examination may ideally add to the educating and learning procedure of English language by revealing more insight into the techniques and speculation that can be actualized inside the study hall, which may expand our learners' appreciation capacities.

\section{METHOD}

\subsection{Participants}

The participants of this study were 50 students who were selected among 80 pre-intermediate learners from a privateEnglish Language Institute. The participants' age range was between 14 and 16. They had been studying English as a foreign language for at least 3 years. They were pre-intermediate students and their level of English language proficiency was determined on the basis of their scores on the Oxford Quick Placement Test (OQPT). The learners were randomly divided into two experimental and control groups. It should be mentioned that only maleswere included in this study since the researcher could easily access to them.

\subsection{Instruments}

\subsubsection{Oxford Quick Placement Test (OQPT)}

The first instrument which wasused in the present study to homogenize the participants' level of proficiency was the OQPT. This instrument was used to collect information on the learners' 
proficiency. Based on this test, those students whose scores were between 27 and 35 participated in the study as pre-intermediate group.

\subsubsection{Pre-Test and Post-Test}

Eight passages and their comprehension questions were extracted from the students' course book and used in this study. The eight passages were chosen based on the familiarity of the topic to the students. Then 40 multiple-choice questions were prepared based on these 8 passages. At the end of the experiment, to find about the possible effects of the Swain's pushed output hypothesison the students' reading comprehension, the pre-test was used again. In fact, the same test was used twice in this study, once as a pre-test and once as a posttest instrument. All characteristics of the post-test were the same as those of the pre-test in terms of time and the number of items. The only difference of this test from the pre-test was that the order of passages, questions and alternatives was changed to wipe out the probable recall of pre-test answers. This was important in order to find out whether the participants were able to choose the correct answer after the treatment was given to them. The allotted time was 70 minutes and each item received one point.

The mentioned test received some reliability and validity measures. After construction, it was examined by ten experts for its face and content validity. The reliability of the pre-test and post-test was computed through the application of Cronbach Alpha formula and values of.898 and .956 were obtained respectively.

\subsubsection{Data Collection Procedures}

At first, the researcher administered the OQPT among 80 students to select 50 homogenous students. After selecting 50 homogenous participants, the researcher randomly divided them into two groups; one control group $(n=25)$ and one experimental group $(n=25)$. The researcher gave the reading comprehension pre-test to the both groups. Then, the participants of experimental group received the treatment. Regarding the treatment, the experimental group was taught by using the explicit task on using push out tasks, while the control group did not receive any treatment and tasks.After the treatment, the posttest was run to measure the effectiveness of the treatment on the students' reading comprehension. When the data were all gathered via pretest and posttest, it was time to carry out the analysis.

\subsubsection{Data Analysis Procedures}

In order to analyze the data, Statistical Package for Social Science (SPSS) software version 25 was used. Firstly,Kolmogorov-Smirnov (K-S) test was used in order to check the normality of the data. Secondly, descriptive statistics including means and standard deviation were calculated. Finally, to examine the impacts of the treatment on Iranian EFL learners' vocabulary knowledge, a one-way ANCOVAwas run.

\section{RESUlts}

Before conducting any analyses on the pretest, and posttest, it was necessary to check the normality of the distributions. Thus, Kolmogorov-Smirnov test of normality was run on the data obtained from the above-mentioned tests. The results are shown in Table 1:

Table1: One-Sample Kolmogorov-Smirnov Test (Groups' Pre and Post-tests)

\begin{tabular}{|c|c|c|c|}
\hline & \multicolumn{3}{|c|}{ Kolmogorov-Smirnov $^{\mathbf{a}}$} \\
\cline { 2 - 4 } & Statistic & df & Sig. \\
\hline EG. Pre & .499 & 25 & .098 \\
\hline EG. Post & .214 & 25 & .114 \\
\hline CG. Pre & .468 & 25 & .124 \\
\hline CG. Post & .450 & 25 & .083 \\
\hline
\end{tabular}

Note: EG: Experimental Group; CG: Control Group; Pre: Pretest; Post: Posttest

The $p$ values under the Sig. column in Table 1 determine whether the distributions were normal or not. A $p$ value greater than .05 shows a normal distribution, while a $p$ value lower than .05 indicates that the distribution has not been normal. Since all the $p$ values in Table 1 were larger than .05 , it could be concluded that the distributions of scores for the pretest and posttest obtained from EG and CG 
The Impact of Swain's Pushed Output Hypothesis on Enhancing Iranian EFL Learners' Reading Comprehension

learners had been normal. It is thus safe to proceed with parametric test (i.e. One-way ANCOVA in this case) and make further comparisons between the participating groups.

As the research question of the study was intended to figure out whether push output vocabulary instructionhave any significant effect on Iranian EFL learners' reading skill, the posttest scores of the EG and CG learners had to be compared. To attain this objective, the researcher could run an independent-samples $t$ test, but to control for any possible pre-existing differences between these two subgroups, and compare their post-test scores accordingly, one-way ANCOVA was chosen to be conducted:

Table2: Descriptive Statistics for Comparing the Post-test Scores of the EG and CG Learners

\begin{tabular}{|l|l|l|l|l|}
\hline \multicolumn{4}{|c|}{ Dependent Variable: Posttest } \\
\hline \multicolumn{1}{|c|}{ Groups } & \multicolumn{1}{|c|}{ Mean } & Std. Deviation & \multicolumn{2}{c|}{ N } \\
\hline Experimental Group & 18.2120 & 1.43129 & 25 & \\
\hline Control Group & 15.8000 & 8.01951 & 25 \\
\hline Total & 17.0060 & 5.82988 & 50 \\
\hline
\end{tabular}

In Table 3, it could be found that the post-test mean score of the EG learners $(M=18.2120)$ was larger than the post-test mean score of the CG learners $(M=15.8000)$. To find out whether this difference was a statistically significant one or not, the researcher had to look down the Sig. column and in front of the Groups row in Table 3:

Table4: Results of One-Way ANCOVA for Comparing the Post-test Scores of the EG and CG Learners

\begin{tabular}{|l|l|l|l|l|l|l|}
\hline \multicolumn{7}{|c|}{ Tests of Between-Subjects Effects } \\
\hline \multicolumn{1}{|c|}{ Source } & $\begin{array}{c}\text { Type III Sum of } \\
\text { Squares }\end{array}$ & \multicolumn{1}{|c|}{ df } & $\begin{array}{c}\text { Mean } \\
\text { Square }\end{array}$ & F & Sig. & \multicolumn{1}{c|}{$\begin{array}{c}\text { Partial Eta } \\
\text { Squared }\end{array}$} \\
\hline Corrected Model & $909.716^{\text {a }}$ & 2 & 454.858 & 28.290 & .000 & .546 \\
\hline Intercept & 831.101 & 1 & 831.101 & 51.691 & .000 & .524 \\
\hline Pretest & 836.995 & 1 & 836.995 & 52.058 & .875 & .000 \\
\hline Groups & 84.371 & 1 & 84.371 & 5.248 & .000 & .564 \\
\hline Error & 755.672 & 47 & 16.078 & & & \\
\hline Total & 16125.590 & 50 & & & & \\
\hline Corrected Total & 1665.388 & 49 & & & & \\
\hline a. R Squared = .546 (Adjusted R Squared $=.527)$ & & & & \\
\hline
\end{tabular}

In Table 3, if you find the row labeled Groups in the leftmost column, and read across this row, under theSig. column, you can find the $p$ value, which should be compared with the alpha level of significance (i.e., .05). The $p$ valuehere was lower than the alpha level of significance $(.000<.05)$, which indicates that the difference between the two groups of EG $(M=18.2120)$ and CG $(M=$ 15.8000) on the reading post-test was statistically significant. This means that using the flipped classroom instruction could significantly improve the writing learning of the EG learners.

Another noteworthy piece of information in Table 4 is the effect size value, shown under the Partial Eta Squared column in front of Groups. This value equaled .494, which means that the treatment (i.e., using Swain's push output vocabulary instruction) accounted for $56 \%$ of the difference between the EG and CG learners.

\section{DISCUSSION AND CONCLUSION}

The findings of this study revealed that there was not any significant difference between reading skill of control and experimental groups on the pre-test. Butboth groups had different performance on their post-test. In fact, the experimental group outperformed the control group on the post-test. This difference can be attributed to the Swain's push output vocabulary instruction, therefore, the null hypothesis of this study "There is not any significant difference between Iranian EFL learners' reading comprehension when they are instructed in push output vocabulary instruction compared to the traditional instructions" is rejected.

It is clearly obvious from the tables that there were contrasts between the mean scores of the learners in the test gathering and the control gathering post-test. This demonstrates the learners in the exploratory gathering performed superior to anything the learners in the control bunch in the reading 
post-test because of the extraordinary impact of utilizing push out assignments and exercises that energize the learners in the test gathering to utilize and deliver the language. This prompts a sort of clear improvement for the learners in the trial bunch therefore to the utilization of push out theory.

The findings of the present paper goes in amicability with studies led by Basterrechea, Mayo, and Leeser (2014) who explore the impact of utilizing the push out errands for the students to see and decide the advancement that the students could accomplish in the wake of getting consistent push out assignments. They uncover that push out exercises has the favorable position to give EFL students an opportunity to do such assignments effectively and adequately. Moreover, some different examinations even found that there is huge job of push out-when exhibiting some of vocabulary exercises to have the option to see the required lexical things. What's more, it has an extraordinary job in helping the students to improve their vocabulary information of EFL students (Keshmirshekan, Namaziandost, \&Pournorouz, 2019). They uncover that introduction of vocabulary undertakings in the grouping of push out preceding info upgrade seeing vocabulary learning hole and create vocabulary information. It might be not the same as Shekary's investigation (2004) as it manages online exchange, while the present examination focuses on composed and spoken arrangement. It is likewise not the same as Zhang's investigation (2009) as his examination focuses on building up the Chinese learners' speaking ability while this investigation focuses on creating Jordanian reading expertise. The reason for the present examination was to research the impact of push out exercises in language procurement that depends on Swain's push out speculation (1985) on advancing Jordanian language students' reading execution. The consequences of the examination uncovered that the test gathering's post-test scores were significantly higher than those of the control gathering. These outcomes demonstrated that training dependent on Swains' push out speculation was fruitful to build up the learners' reading execution. This paper has demonstrated that learners indicated progress in EFL readingcomprehension as well as in learning of push out errands. With these assignments and directions, learners had the option to build up their mindfulness in utilizing other reading systems. Additionally, learners' frames of mind changed emphatically toward reading in an unknown language. They increased self-assurance that they could connect with various types of readings texts.

\section{REFERENCES}

[1] Abadikhah,S and Zarrabi,F. (2011).The Effect of Output Tasks on the Acquisition of English Verbal Morphemes. Theory and Practice in Language Studies, 1(11), 1549- 1560.

[2] Abedi, P., Keshmirshekan, M. H., \&Namaziandost, E. (2019). The comparative effect of flipped classroom instruction versus traditional instruction on Iranian intermediate EFL learners' English composition writing. Journal of Applied Linguistics and Language Research, 6(4), 43-56.

[3] Anderson, R. C., \& Freebody, P. (1981). Vocabulary knowledge. In J. Guthrie (Ed.), Comprehension and teaching: Research reviews (pp. 77-117). Newark, DE: International Reading Association.

[4] Azadi, G., Biria, R., \&Nasri, M. (2018). Operationalising the Concept of Mediation in L2 Teacher Education. Journal of Language Teaching and Research, 9(1), 132-140.

[5] Basterrechea, M., Mayo, M. P. G., \&Leeser, M. (2014). Pushed Output and Noticing in a Dictogloss: Task Implementation in the CLIL Classroom. Retrieved September 13,2019 fromhttp://www.ugr.es/ portalin/ articulos/PL_numero22/1\%20\%20Maria\%20 Basterrech

[6] Gass, S. M. (1997). Input, Interaction, and the Second Language Learner. Mahwah, NJ: Lawrence Erlbaum Associates, Publishers.

[7] Hashemifardnia, A., Namaziandost, E., \&Sepehri, M. (2018). The effectiveness of giving grade, corrective feedback, and corrective feedback-plus-giving grade on grammatical accuracy. International Journal of Research Studies in Language Learning, 8 (1), 15-27.

[8] Hashemifardnia, A., Namaziandost, E., Shafiee, S. (2018).The Effect of Implementing Flipped Classroomson Iranian Junior High School Students' Reading Comprehension. Theory and Practice in Language Studies, 8(6), 665-673.

[9] Hosseini, E. Z., Nasri, M., \&Afghari, A. (2017). Looking beyond teachers' classroom behavior: novice and experienced EFL teachers' practice of pedagogical Knowledge to Improve Learners' Motivational Strategies. Journal of Applied Linguistics and Language Research, 4(8), 183-200.

[10] Izumi, S. (2002).Output, input enhancement, and the noticing hypothesis. Retrieved March 15, 2017 from https://www.researchgate.net/publication/231781443_Output_input_enhancement_and_the_noticing_hypothesis.

[11] Izumi, S., \& Bigelow, M. (2000). Does Output Promote Noticing and Second Language Acquisition? TESOL Quarterly, 34(2), 239-278. http://dx.doi.org/10.2307/3587952. 
[12] Keshmirshekan, M. H., Namaziandost, E., \&Pournorouz, M. (2019). The Impacts of Creative Writing Activities on Iranian EFL Learners' Progress in Writing, Writing Dispositions: Focus on Attitude to English Course. EPH - International Journal of Educational Research, 3(9), 12-22.

[13] Krashen, S. D. (1980). The input hypothesis: Issues and implications. In J.Alatis (Ed.), Current issues in bilingual education (pp. 144-158). Washington, D.C.: Georgetown University Press.

[14] Laufer B. and Sim, D.D. (1985). Measuring and explaining the reading threshold needed for English for academic purposes texts. Foreign Annals, 18(5), 405-411.

[15] Laufer, B. (1992b). Reading in a foreign language: How does lexical knowledge interact with the reader's general academic ability? Journal of Research in Reading, 15(2), 95-103.

[16] Leeser, M. J. (2008). Pushed output, noticing, and development of past tense morphology in content-based instruction. Canadian Modern Language Review, 65, 2: 195-220.

[17] Long, M. (1996). The role of the linguistic environment in second language acquisition. In W. C. Ritchie \& T. K. Bhatia (Eds.), Handbook of second language acquisition (pp. 413- 468). New York: Academic Press.

[18] Mahmoudabadi, Z., Soleimani, H., Jafarigohar, M., \&Iravani, H. (2015). The effect of sequence of output tasks on noticing vocabulary items and developing vocabulary knowledge of Iranian EFL learners. International Journal of Asian Social Science, 5(1), 18-30.

[19] Mirshekaran, R., Namaziandost, E., \& Nazari, M. (2018). The Effects of Topic Interest and L2 Proficiency on Writing Skill among Iranian EFL Learners. Journal of Language Teaching and Research, 9(6), 1270-1276.

[20] Nagy, W., \& Herman, P. (1987). Breadth and depth of vocabulary knowledge: Implications for acquisition and instruction. In M. McKeown \& M. Curtis (Eds.), the nature of vocabulary acquisition (pp. 19-35). Hillsdale, NJ: Erlbaum.

[21] Nagy, W., Herman, P., \& Anderson, R. C. (1985). Learning words from context. Reading Research Quarterly, 20(2), 233-253.

[22] Namaziandost E., \&Nasri, M. (2019a).A meticulous look at Long's (1981) interaction hypothesis: does it have any effect on speaking skill? Journal of Applied Linguistics and Language Research, 6(2), 218-230.

[23] Namaziandost E., \&Nasri, M. (2019b).The impact of social media on EFL learners' speaking skill: A survey study involving EFL teachers and students.Journal of Applied Linguistics and Language Research, 6(3), 199-215.

[24] NamaziandostE., \&Shafiee, S. (2018). Gender Differences in the Use of Lexical Hedges in Academic Spoken Language among Iranian EFL Learners: A Comparative Study. International Journal of Research in English Education, 3(4), 64-80

[25] Namaziandost, E., \& Ahmadi, S., Keshmirshekan, M. H. (2019). Listening comprehensions problems and strategies used by intermediate EFL learners. Journal of English Literature and Cultural Studies (JELCS Journal), 2(3), 28-41.

[26] Namaziandost, E., \&Nasri, M., Rahimi Esfahani, F., \&KeshmirshekanM. H. (2019). The impacts of spaced and massed distribution instruction on EFL learners' vocabulary learning. Cogent Education, 6: 1661131. https://doi.org/10.1080/2331186X.2019.1661131.

[27] Namaziandost, E., Abedi, P., \&Nasri, M. (2019). The Role of Gender in the Accuracy and Fluency of Iranian Upper-intermediate EFL Learners' L2 Oral Productions. Journal of Applied Linguistics and Language Research, 6(3),110-123

[28] Namaziandost, E., Fatahi, M., \&Shafiee, S. (2019).The Relationship between Iranian Upper-Intermediate EFL Learners' Contrastive Lexical Competence and Their Use of Vocabulary Learning Strategies. International Journal of Foreign Language Teaching \& Research - 7(28),105-120.

[29] Namaziandost, E., Hashemifardnia, A., \&Shafiee, S. (2019). The impact of opinion-gap, reasoning-gap, and information-gap tasks on EFL learners' speaking fluency. Cogent Social Sciences 5, 1630150 https://doi.org/10.1080/23311886.2019.1630150

[30] Namaziandost, E., Nasri, M., \&Keshmirshekan, M. H. (2019). Cohesive conjunctions in applied linguistics research articles among Iranian and non-Iranian researchers: A comparative corpus-based study. Journal of English Language Studies, 4(2), 101 - 119.

[31] Namaziandost, E., Rahimi Esfahani, F., \& Ahmadi, S. (2019).Varying levels of difficulty in L2 reading materials in the EFL classroom: Impact on comprehension and motivation. Cogent Education, 6, 1-9. https://doi.org/10.1080/2331186X.2019.1615740.

[32] Namaziandost, E., Rahimi Esfahani, F., Nasri, M., \&Mirshekaran, R. (2018). The Effect of Gallery Walk Technique on Pre-intermediate EFL Learners' Speaking Skill. Language Teaching Research Quarterly, 8, 1-15.

[33] Namaziandost, E., Sabzevari, A., \&Hashemifardnia, A. (2018). The effect of cultural materials on listening comprehension among Iranian upper-intermediate EFL learners: In reference to gender. Cogent Education,5(1), 1-27. https://doi.org/10.1080/2331186X.2018.1560601. 
[34] Nasri, M. \&Biria, R. (2017). Integrating multiple and focused strategies for improving reading comprehension and 12 lexical development of Iranian intermediate EFL learners. International Journal of Applied Linguistics \& English Literature, 6(1), 311-321.

[35] Nasri, M., Biria, R., \& Karimi, M. (2018). Projecting Gender Identity in Argumentative Written Discourse. International Journal of Applied Linguistics \& English Literature, 7(3), 201-205.

[36] Nasri, M., Namaziandost, E., \& Akbari, S. (2019). Impact of pictorial cues on speaking fluency and accuracy among Iranian pre-intermediate EF learners. International Journal of English Language and Literature Studies, 8(3), 99-109

[37] National Reading Panel (2000). Teaching children to read: An Evidence-Based Assessment of the Scientific Research Literature on Reading and Its Implications for Reading Instruction. Washington, DC: National Institute of Child Health and Development. Report of the National Reading Panel. Washington, DC: National Institute of Child Health and Human Development.

[38] Rahimian, M. (2013). Negotiation of Meaning and Modified Output Elicitation across Two Tasks. English Language Teaching, 6 (12), 114-128.

[39] Shekary, M. (2004). Negotiation of meaning and noticing in cyberspace: The role of text-based on-line chat in the development of SLA. (Unpublished MA thesis). University of Isfahan, Isfahan, Iran.

[40] Swain, M. (1985). Communicative competence: some roles for comprehensible input and comprehensible output in its development. In S. Gass\& C. Madden (Eds.) Input and Second Language Acquisition. Rowley, MA: Newbury House

[41] Wilkins, D.A. (1972). Linguistics in Language Teaching. Australia: Edward Arnold.

[42] Zhang,S. (2009). The Role of Input, Interaction and Output in the Development. English language Teaching, 2(4), 91-100.

\section{AUTHORS' BIOGRAPHY}

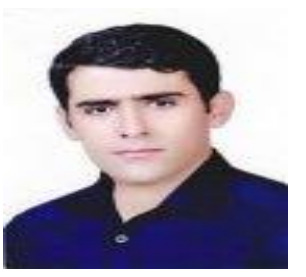

Ehsan Namaziandost was born in Shiraz Province of Iran in 1985. He holds an MA degree in TEFL from Islamic Azad University of Ahvaz. Now, he is Ph.D. candidate of TEFL at Islamic Azad University, Shahrekord, Iran. His main interests of research are second language acquisition, EFL teaching and testing, teaching language skills, and language learning strategies. His research papers and articles have been published by different international journals.

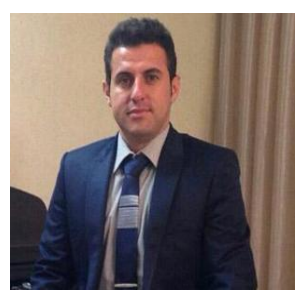

Mehdi Nasri was born in Isfahan، Iran. He holds a master's degree in TEFL from Islamic Azad University of Isfahan (Khorasgan). He is currently studying $\mathrm{PhD}$ in TEFL at Islamic Azad University of Shahrekord, Iran. He published some articles in different international journals and presented some ones in national conferences in Iran. His areas of interest are second language vocabulary learning and teaching, pragmatics, and reading comprehension.

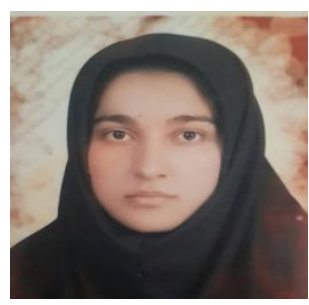

Sheida Ahmadi was born in Tehran province of Iran in 1989. She holds a BA degree in English literature from State Unversity of Malayer. She holds TESOl certificate from ITTI of New York. Her main interests of research are literature, teaching methods and language learning methods. Her research papers have been published by various international journals.

Citation: Ehsan Namaziandost, Mehdi Nasri, Sheida Ahmadi. The Impact of Swain's Pushed Output Hypothesis on Enhancing Iranian EFL Learners' Reading Comprehension. "International Journal on Studies in English Language and Literature (IJSELL), vol 7, no. 10, 2019, pp. 11-20. doi: http://dx.doi.org/10.20431/ 2347-3134.0710002.

Copyright: (C) 2019 Authors. This is an open-access article distributed under the terms of the Creative Commons Attribution License, which permits unrestricted use, distribution, and reproduction in any medium, provided the original author and source are credited. 